\title{
STRATEGI PENGELOLAAN ASET TETAP DI KECAMATAN KEJAKSAN KOTA CIREBON
}

\author{
The Strategies for Management of Fixed Assets in Kejaksan District of Cirebon
}

\author{
Nurani Yuni Purwanti ${ }^{1}$, Anna Fariyanti ${ }^{2}$, Nirwan Ristiyanto ${ }^{3}$
}

\begin{abstract}
1 Staf Badan Kepegawaian Pendidikan Pelatihan Daerah Kota Cirebon. Email: rhannee83@gmail.com 2Staff Pengajar Departemen Agribisnis. Fakultas Ekonomi dan Manajemen, IPB. E-mail: a_fariyanti@yahoo.com 3Pengajar Pusat Pendidikan dan Pelatihan Pengawasan (Pusdiklatwas), Badan Pengawasan Keuangan dan Pembangunan RI. Email: nirwanristiyanto@yahoo.com
\end{abstract}

\begin{abstract}
Regional assets are an important component of governance and public services. Management of good local assets to produce information in the preparation of financial statements must meet the completeness of the document management of local property in accordance with the regulations. The purpose of this study is to formulate the strategies for management of fixed assets in Kejaksan district. Analytical methods which were specifically implemented in order to achieve the purpose of the study are descriptive analysis, likert scale, and Analytical Hierarchy Process (AHP). Sources of data used in this study are questionnaires and interviews to 10 managers of fixed assets in in Kejaksan district and 4 expert respondents .Strategies resulting from Analytical Hierarchy Process (AHP) are: (1) technical guidance of fixed asset management, (2) guidance and control of direct supervisor, (3) application of reward and punishment, (4) periodic asset management socialization , (5) improvement of infrastructure facilities for fixed asset management, and (6) policy making on the management of new fixed assets.
\end{abstract}

Keywords: Management Of Fixed Assets, Techcical Guidance, Guidance And Control, Facilities Infrastructure, Analytical Hierarchy Process

\begin{abstract}
ABSTRAK
Aset daerah merupakan komponen penting dalam penyelenggaraan pemerintahan dan pelayanan publik. Pengelolaan aset daerah yang baik guna menghasilkan informasi dalam penyusunan laporan keuangan harus memenuhi kelengkapan dokumen pengelolaan barang milik daerah sesuai peraturan yang berlaku. Tujuan dari penelitian ini adalah untuk merumuskan strategi perbaikan dengan menggunakan Analytical Hierarchy Process. Sumber data yang digunakan dalam penelitian ini adalah kuesioner dan wawancara kepada 4 responden yang dianggap ahli. Strategi perbaikan yang dihasilkan dari Analytical Hierarchy Process (AHP) adalah: (1) pembinaan teknis pengelola aset tetap, (2) pembinaan dan pengendalian dari atasan langsung, (3) penerapan reward dan punishment, (4) sosialiasi pengelolaan aset secara berkala, (5) peningkatan sarana prasarana pengelola aset tetap, dan (6) pembuatan kebijakan mengenai pengelolaan aset tetap terbaru.
\end{abstract}

Kata Kunci: Pengelolaan Aset Tetap, Pembinaan Teknis, Pembinaan Dan Pengendalian, Sarana Prasarana, Analytical Hierarchy Process

\section{PENDAHULUAN}

Aset daerah merupakan komponen penting dalam penyelenggaraan pemerintahan dan pelayanan publik. Aset daerah perlu dikelola secara baik karena terjadi peningkatan nilai setiap tahun. Aset daerah menjadi modal bagi pemerintah daerah untuk melakukan pengembangan dalam menunjang peran dan fungsi pemerintah daerah sebagai pemberi pelayanan publik kepada masyarakat. Pelaksanaan otonomi daerah pada dasarnya bertujuan untuk memandirikan suatu daerah agar dapat mengelola segala sesuatu di dalam daerahnya tersebut termasuk pengelolaan keuangan dan aset.

Pengelolaan barang milik daerah tidak hanya membutuhkan sumber daya manusia, tetapi juga sumber daya ekonomi berupa keuangan yang dituangkan dalam suatu anggaran pemerintah daerah (Wonggow et al. 2014). Barang milik daerah merupakan barang yang dibeli atau diperoleh atas beban Anggaran Pendapatan 
dan Belanja Daerah, atau perolehan lainnya yang sah.

Peraturan Pemerintah No. 6 Tahun 2006 merupakan peraturan turunan dari Undang-Undang No.1 Tahun 2004 tentang Perbendaharaan Negara yang menimbulkan optimisme baru dalam penataan dan pengelolaan aset daerah yang lebih tertib, akuntabel, dan transparan untuk kedepannya (Rizqi et al. 2013). Pengelolaan aset daerah diatur dalam peraturan terbaru yaitu Peraturan Pemerintah No. 27 Tahun 2014 tentang Pengelolaan Barang milik Negara/Daerah, yang kemudian ditindaklanjuti dengan Peraturan Menteri Dalam Negeri No.19 Tahun 2016 tentang Pedoman Pengelolaan Barang Milik Daerah. Untuk menerapkan sistem yang sesuai dengan Permendagri No. 19 Tahun 2016 diperlukan pengawasan dan kerjasama yang mampu melaksanakan proses pencatatan asset ditingkat SKPD maupun pengelola barang milik daerah secara teliti dan kompeten (Saren et al. 2016).

Pemerintah Kota Cirebon memperoleh opini WDP sejak tahun 2010 sampai dengan 2015. Pengecualian yang sering muncul adalah mengenai kurang efektifnya sistem pengendalian intern Pemerintah Kota Cirebon terhadap pengelolaan asset (BPK, 2011-2016). Kecamatan Kejaksan adalah salah satu Satuan Kerja Perangkat Daerah di Pemerintah Kota Cirebon. Berdasarkan data pemeriksaan Inspektorat Kota Cirebon tahun 2016, menunjukkan bahwa Kecamatan Kejaksan belum melakukan pengelolaan aset dengan baik. Hal ini ditunjukkan dengan belum adanya RKBUMD (Rencana Kebutuhan Barang Unit Milik Daerah) dan RKPBUMD (Rencana Kebutuhan Pemeliharaan Barang Unit Milik Daerah) tahun 2017, belum dilakukan pencatatan dan kodefikasi atas pengadaan peralatan dan mesin tahun 2016, tidak dibuatnya laporan semesteran barang penerimaan dan pengeluaran barang tahun 2016.

Berdasarkan hal tersebut, rumusan masalah dalam penelitian ini yaitu bagaimana strategi pengelolaan aset tetap di Kecamatan Kejaksan Kota Cirebon?. Tujuan penelitian ini adalah untuk merumuskan strategi pengelolaan aset tetap di Kecamatan Kejaksan Kota Cirebon.

\section{METODE PENELITIAN}

Penelitian ini menggunakan data primer melalui wawancara dan kuesioner Analytical Hierarchy Process (AHP) terhadap 4 responden dari Inspektorat, Bidang Aset Badan Keuangan Daerah, Kecamatan Kejaksan dan akademisi di Universitas Swadaya Gunung Jati. Pengumpulan data dilakukan pada bulan Juni 2017.

Penelitian ini dalam memformulasikan strategi menggunakan Analytical Hierarcy Process (AHP) dengan bantuan aplikasi Expert Choice 11 dalam mengolah data. Saaty (1993) menyatakan AHP sebagai suatu model yang luwes yang memberikan kesempatan bagi perorangan atau kelompok untuk membangun gagasan-gagasan dan mendefinisikan persoalan dengan cara membuat asumsi mereka masing-masing dan memperoleh pemecahan yang diinginkan darinya. Keluwesan AHP digunakan untuk memadukan aspek kualitatif dalam mendefinisikan persoalan dan hirarkinya dan aspek kuantitatif dalam mengekspresikan penilaian preferensi secara ringkas dan padat. Menurut Saaty (1993) prinsip dasar AHP ada tiga, yaitu:

\section{Penyusunan Hierarki}

Hierarki merupakan alat mendasar pikiran manusia. Penyusunan hierarki dilakukan dengan cara mengidentifikasi pengetahuan atau informasi yang sedang diamati. Penyusunan tersebut dimulai dari permasalahan yang kompleks dan diuraikan menjadi elemen pokoknya. Elemen pokok ini diuraikan lagi ke dalam bagian-bagian yang lebih detail dan seterusnya. Penyusunan hirarki secara praktis dapat dijelaskan sebagai berikut. Pertama adalah mengindentifikasi tujuan keseluruhan pembuatan hirarki atau "goal" 
yang disebutkan disini adalah masalah yang akan dicari pemecahannya lewat metode AHP. Setelah itu menentukan kriteria-kriteria yang diperlukan atau sesuai dengan tujuan keseluruhan tersebut. Kriteria ini biasanya terdiri dari syaratsyarat atau keadaan yang kiranya dapat menunjang tercapainya sebuah "goal" dan biasanya bersifat umum (general). Sejalan dengan hal tersebut maka perlu dipertimbangkan kemungkinan penambahan sub-sub kriteria dibawah setiap kriteria. Sub kriteria merupakan penjabaran lebih detail dari kriteria yang masih bersifat umum tersebut. Terakhir, identifikasikan alternatif-alternatif yang akan dievaluasi di bawah sub-sub kriteria.

Tujuan akhir dari perumusan strategi menggunakan analisis AHP adalah pemilihan prioritas strategi yang paling baik untuk strategi perbaikan pengelolaan aset tetap. Adapun alternatif strategi pada level 4 yaitu: (1) pendidikan dan pelatihan SDM (2) pembinaan rutin SDM (3) sosialisasi pengelolaan aset secara berkala (4) peningkatan sarana-prasarana pengelola aset tetap (5) pembinaan dan pengendalian dari atasan langsung (6) penerapan sistem reward dan punishment.

\section{Penetapan Prioritas}

Langkah pertama yang dilakukan adalah dengan membuat perbandingan berpasangan (pairwise comparisons) untuk menentukan prioritas. Elemen-elemen dibandingkan berpasangan terhadap kriteria tertentu dan menimbang intensitas preferensi antar elemen. Hubungan antar elemen dari setiap tingkatan hierarki ditetapkan dengan membandingkan elemen itu dalam pasangan. Bentuk dari perbandingan ini biasanya dalam bentuk matriks.

Dalam memulai proses perbandingan ini, dimulai pada puncak hirarki untuk memilih kriteria atau sifat yang akan digunakan untuk melakukan pernbandingan yang pertama (goal). 60 Kemudian elemen tingkat bawahnya dibandingkan seperti terlihat di Tabel 1.
Nilai yang didapatkan dari hasil penilaian matriks seperti pada Tabel 9, kemudian diolah untuk menentukan peringkat relatif dari seluruh alternatif. Setiap level hierarki baik kuantitatif dan kualitatif dapat dibandingkan sesuai judgment yang telah ditentukan untuk menghasilkan bobot dan prioritas.

\section{Konsistensi Logis}

Semua elemen dikelompokkan secara logis dan diperingkatkan secara konsisten sesuai dengan suatu kriteria yang logis. Penilaian yang mempunyai konsistensi tinggi sangat diperlukan dalam pengambilan keputusan agar hasil keputusan akurat. Konsistensi dalam batas tertentu dalam menetapkan prioritas sangat diperlukan untuk memperoleh nilai-nilai yang benar dalam dunia nyata.

\section{HASIL DAN PEMBAHASAN}

\section{Perumusan Strategi Pengelolaan Aset Tetap}

Perumusan strategi pengelolaan aset tetap di Kecamatan Kejaksan Kota Cirebon menggunakan metode Analytical Hierarchy Process (AHP). Struktur hirarki metode AHP mencakup level fokus, faktor, aktor, kendala, dan prioritas strategi pengelolaan aset tetap. Faktor-faktor yang digunakan dalam penyusunan hirarki prioritas strategi yang dianggap menjadi faktor yang menentukan strategi pengelolaan aset tetap yaitu:

1. Sumber Daya Manusia merupakan manusia yang bekerja dalam organisasi, berperan dan memahami pekerjaannya dalam pengelolaan aset tetap, baik sebagai pengambil kebijakan maupun sebagai pelaksana.

2. Sarana Prasarana merupakan sarana yang dibutuhkan untuk mendukung pekerjaan pengelola aset tetap seperti komputer dan jaringan internet.

3. Komitmen Pimpinan merupakan janji pimpinan untuk melakukan perbaikan dalam pengelolaan aset tetap untuk mencapai tujuan organisasi. 
Aktor-aktor yang berperan dalam strategi perbaikan pengelolaan aset tetap di Kecamatan Kejaksan adalah Camat Kejaksan, Bidang Aset Badan Keuangan Daerah, dan Inspektorat Kota Cirebon. Adapun peran dari masing-masing aktor adalah sebagai berikut:

1. Camat Kejaksan sebagai pengguna barang yaitu pejabat pemegang kewenangan penggunaan barang milik daerah (Kemendagri 2016).

2. Inspektorat berperan sebagai aparat pengawasan intern pemerintah yang berhak untuk melakukan audit atas pelaksanaan pengelolaan barang milik daerah (Kemendagri 2016).

3. Bidang Aset Badan Keuangan Daerah sebagai pengurus barang pengelola yaitu pejabat yang diserahi tugas menerima, menyimpan, mengeluarkan, dan menatausahakan barang milik daerah pada Pejabat Penatausahaan Barang (Kemendagri 2016).

Kendala dalam mencapai perbaikan pengelolaan aset tetap di Kecamatan Kejaksan adalah sebagai berikut:

1. Perubahan kebijakan mengenai pengelolaan aset tetap

Kebijakan yang masih digunakan saat ini dianggap sudah tidak relevan dengan kondisi sebenarnya dan belum mengikuti peraturan mengenai pengelolaan aset terbaru sehingga pemerintah Kota Cirebon perlu membuat peraturan daerah menyesuaikan dengan Peraturan Menteri Dalam Negeri terbaru. Hukum dan peraturan adalah hal mendasar yang menjadi landasan pemerintah atas pengelolaan aset tetap. Landasan tersebut terdiri dari komponen-komponen seperti kebijakan, undang-undang, peraturan, prosedur, norma dan pedoman. Hukum dan peraturan yang berkualitas sangat menentukan efektivitas pengelolaan aset dalam mencapai tujuan dan sasarannya. (Lu 2011).
2. Kurangnya kompetensi SDM pengelola aset tetap

Sumber Daya Manusia (SDM) menjadi kekuatan utama dalam suatu organisasi. Oleh karena itu organisasi memerlukan kompetensi SDM pengelola aset yang handal agar pengelolaan aset dapat berjalan sesuai peraturan, dapat dipertanggungjawabkan dan dapat menghasilkan laporan keuangan yang baik.

3. Kurangnya komunikasi dan koordinasi dengan partner kerja

Pengelolaan aset tetap pada pelaksanaannya juga melibatkan bagian keuangan dalam organisasi tersebut sehingga pentingnya menjaga komunikasi dan koordinasi dengan partner kerja seperti bagian keuangan. Kurangnya komunikasi dan koordinasi dengan partner kerja ini merupakan tanda bahwa ada masalah komunikasi horizontal, yang termasuk dalam struktur organisasi organik (Burns dan Stalker 1961 dalam Lu 2011).

4. Kurangnya dukungan seluruh karyawan SKPD/Unit Kerja

Pengelolaan aset tetap bukan hanya menjadi tanggung jawab pengurus barang/pengurus barang pembantu tetapi juga merupakan tanggung jawab seluruh karyawan dalam suatu organisasi sehingga perntingnya dukungan seluruh karyawan untuk ikut terlibat dalam pelaksanaan pengelolaan aset tetap.

5. Kurangnya sarana prasarana pengelola aset tetap

SDM yang mengelola aset tetap membutuhkan sarana prasarana pendukung yang meliputi komputer, printer, jaringan internet, dan aplikasi agar seluruh proses pengelolaan aset tetap dapat berjalan.

6. Kurangnya komitmen pimpinan

Pengelolaan aset tetap yang baik dapat terwujud apabila pimpinan suatu organisasi memiliki komitmen yang kuat untuk memperbaiki pengelolaan aset tetap yang saat ini dinilai kurang baik.

Berdasarkan pemaparan berbagai kendala, aktor yang berperan, dan faktor 
yang mempengaruhi dalam pengelolaan aset, dalam rangka mencapai fokus yaitu perbaikan pengelolaan aset tetap dan untuk mengatasi berbagai kendala dalam pengelolaan aset tetap, maka prioritas strategi yang dipilih adalah sebagai berikut: 1 . Pembuatan kebijakan mengenai pengelolaan aset tetap terbaru, 2 . Pembinaan teknis SDM pengelola aset tetap, 3. Sosialisasi pengelolaan aset secara berkala, 4. Peningkatan sarana-prasarana pengelola aset tetap, 5. Pembinaan dan pengendalian dari atasan langsung, 6 . Penerapan sistem reward dan punishment. Hasil perumusan strategi dengan AHP sesuai dengan hirarki dan urutan prioritas masing-masing level disajikan pada Gambar 1.

Tingkat peranan antar unsur pada setiap level dengan level di atasnya adalah sebagai berikut:

\section{Tingkat Peranan Faktor dalam Pengelolaan Aset Tetap di Kecamatan Kejaksan Kota Cirebon}

Perbandingan antar elemen "Faktor" yang menempati urutan pertama yaitu Komitmen Pimpinan dengan nilai 0,528, urutan selanjutnya adalah Sumber Daya Manusia dengan nilai 0,363, dan Sarana Prasarana dengan nilai 0,109. Pengelolaan aset tetap bisa berjalan dengan baik jika didukung oleh faktor-faktor pendukung yang baik di antaranya Sumber Daya Manusia (SDM), Sarana Prasarana, dan Komitmen Pimpinan. Namun, dalam analisis menggunakan metode AHP untuk Strategi Perbaikan Pengelolaan Aset Tetap, faktor komitmen pimpinan dijadikan faktor yang paling diprioritaskan dibandingkan dua faktor yang lain.

Responden yang dianggap ahli berpendapat bahwa komitmen pimpinan menjadi faktor yang paling diprioritaskan karena segala bentuk perbaikan dapat dicapai apabila pimpinannya memiliki komitmen yang kuat untuk melaksanakan perbaikan tersebut. Komitmen pimpinan untuk mewujudkan perbaikan pengelolaan aset tetap menjadi dasar organisasi untuk merancang kegiatan sehingga organisasi dapat memfokuskan salah satu tujuan organisasinya pada perbaikan pengelolaan aset tetap. Jadi, faktor komitmen pimpinan menjadi prioritas pertama yang perlu diperhatikan untuk kesuksesan proses pengelolaan aset tetap di Kecamatan Kejaksan Kota Cirebon.

Faktor selanjutnya yang dianggap penting yaitu masalah Sumber Daya Manusia (SDM). Faktor SDM menjadi penting karena menyangkut orang-orang yang berperan langsung dalam pengelolaan aset tetap. Pengelolaan aset tetap dapat dinilai baik apabila SDM yang mengelolanya kemiliki kemampuan yang handal, mengerti dan memahami tugasnya, mengetahui peraturan mengenai pengelolaan aset sehingga dapat menerapkan peraturan tersebut pada pekerjannya, memahami tugasnya.

Prioritas ketiga yaitu sarana prasarana. Menurut responden, faktor sarana prasarana menjadi faktor pendukung untuk kesuksesan pengelolaan aset tetap karena tanpa sarana prasarana, pengelolaan aset tetap dapat tetap berjalan.

\section{Tingkat Peranan Aktor Dalam Perbaikan Pengelolaan Aset Tetap Di Kecamatan Kejaksan Kota Cirebon}

Dari hasil pengolahan dengan metode AHP, perbandingan antar unsur “Aktor” Strategi Perbaikan Pengelolaan Aset Tetap di Kecamatan Kejaksan Kota Cirebon, yaitu prioritas pertama adalah Camat Kejaksan dengan nilai 0,716. Prioritas kedua adalah Bidang Aset BKD dengan nilai 0,147 dan prioritas selanjutnya adalah Inspektorat dengan nilai 0,137. Camat Kejaksan memiliki prioritas yang paling tinggi karena Camat Kejaksan merupakan Pengguna Barang sebagai pelaku utama pengelolaan aset tetap di Kecamatan Kejaksan yang dapat mengendalikan baik atau tidaknya pengelolaan aset tetap di instansinya tersebut. 


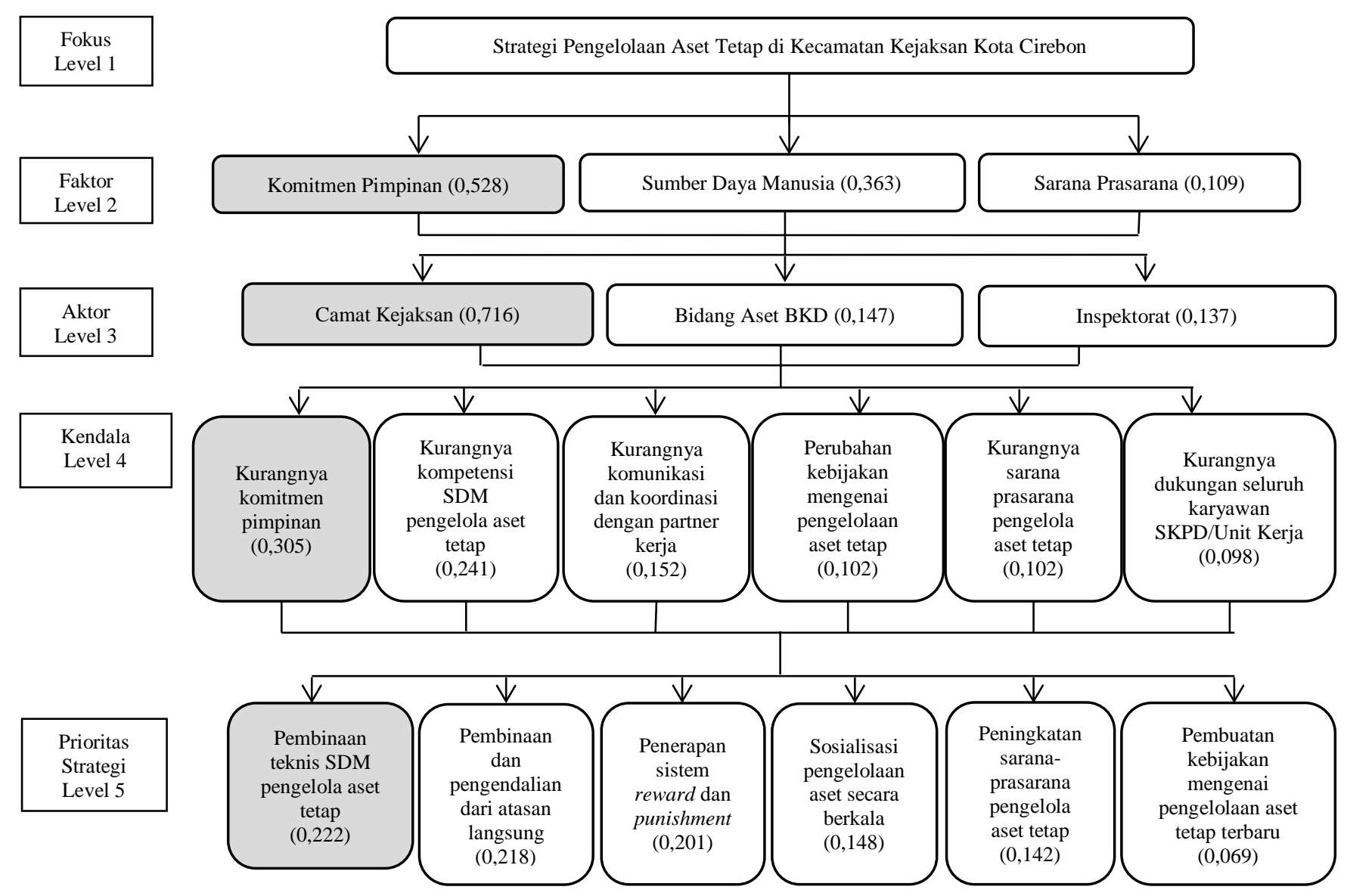

Gambar 1 Struktur dan Nilai Bobot Hirarki AHP

Prioritas selanjutnya adalah Bidang Aset BKD. Bidang Aset BKD merupakan pengurus barang pengelola yang membantu Sekretaris Daerah dalam mengelola barang di tingkat Pemerintah Kota. Perannya besar dalam mengelola aset tetap di tingkat kota sehingga memiliki peran penting dalam perbaikan pengelolaan aset tetap di Kecamatan Kejaksan. Prioritas selanjutnya adalah Inspektorat yang tidak berperan langsung dalam pengelolaan aset tetap. Inspekorat merupakan unsur Aparat Pengawasan Intern Pemerintah (APIP) yang bertugas mengawasi dan membina SKPD di lingkup Pemerintah Kota termasuk Kecamatan Kejaksan.

\section{Tingkat Peranan Kendala Dalam Pengelolaan Aset Tetap di Kecamatan Kejaksan Kota Cirebon}

Perbandingan antar elemen

"Kendala" yang menempati prioritas pertama untuk perbaikan pengelolaan aset yaitu kurangnya komitmen pimpinan dengan nilai 0,305 , prioritas kedua yaitu kurangnya kompetensi SDM pengelola aset tetap dengan nilai 0,241 , prioritas ketiga yaitu kurangnya komunikasi dan koordinasi dengan partner kerja dengan nilai 0,152, prioritas keempat yaitu perubahan kebijakan mengenai pengelolaan aset tetap dan kurangnya sarana prasarana pengelola aset tetap dengan nilai yang sama 0,102, serta prioritas terakhir yaitu kurangnya dukungan seluruh karyawan SKPD/Unit Kerja dengan nilai 0,098.

Menurut ahli yang menjadi responden metode AHP, kurangnya 
komitmen pimpinan menjadi kendala utama dalam perbaikan pengelolaan aset tetap. Hal ini berhubungan dengan peran faktor utama pada perbaikan pengelola aset tetap yaitu faktor Komitmen Pimpinan. Dalam pengelolaan aset tetap, kurang komitmen dari pimpinan dapat menjadi penghambat tidak berhasilnya perbaikan pengelolaan aset tetap ini. Sehingga pimpinan harus secara tegas berkomitmen untuk mewujudkan penataan pengelolaan keuangan dan aset yang baik sesuai misi yang tertuang di dalam Rencana Stratejik tahun 2018.

Kurangnya kompetensi SDM menjadi prioritas berikutnya yang juga sangat penting. SDM sebagai pengelola aset tetap yang utama harus memiliki kualitas yang cukup baik. Kendala yang ada di lapangan adalah kurangnya staf dan masih ada beberapa pengurus barang yang tidak memahami penggunaan aplikasi SIMDA BMD sebagai aplikasi pendukung untuk pencatatan dan pelaporan aset tetap. Tidak adanya penambahan staf karena moratorium PNS memiliki dampak pada kekurangan PNS di seluruh SKPD di Kota Cirebon termasuk Kecamatan Kejaksan dan Kelurahan di bawahnya. SDM yang tersedia seadanya sehingga kemampuannya perlu dimaksimalkan agar dapat mengelola aset dengan baik. SDM yang ditetapkan sebagai pengurus barang sudah dijabat selama bertahun-tahun sehingga mengalami kejenuhan. Hal ini juga menyebabkan turunnya kualitas SDM dalam mengelola aset.

Prioritas ketiga dari elemen kendala yaitu kurangnya komunikasi dan koordinasi dengan partner kerja. Kurangnya komunikasi dan koordinasi dengan partner kerja menyebabkan pengelolaan aset tetap menjadi kurang baik. Pengelolaan aset tetap tidak dapat dilakukan sendiri tanpa dukungan dari atasan langsung, partner kerja dalam hal ini adalah bidang keuangan baik bendahara maupun pencatat akuntansi di SKPD.

Prioritas keempat dari elemen kendala yaitu perubahan kebijakan pengelolaan aset tetap dan kurangnya sarana prasarana pengelola aset tetap. Kebijakan yang terakhir dimiliki Pemerintah Kota adalah Peraturan Daerah No 18 Tahun 2008 yang mengacu pada Peraturan Menteri Dalam Negeri No 17 Tahun 2007. Saat ini telah terbit Peraturan Menteri Dalam Negeri No 19 Tahun 2016 mengenai pengelolaan Barang Milik Daerah. Permendagri tersebut paling lambat diadopsi oleh Kabupaten/Kota di tahun 2017. Sampai dengan saat ini, Pemerintah Kota Cirebon belum memiliki Peraturan Daerah yang menyesuaikan dengan Permendagri terbaru. Prioritas selanjutnya adalah kurangnya sarana prasarana dalam pengelolaan aset tetap. Sarana prasarana sebagai penunjang kinerja pengelola aset, diperlukan untuk mendukung baiknya pengelolaan aset tetap di Kecamatan Kejaksan meliputi komputer/laptop, printer, jaringan inernet. Saat ini di Kelurahan dan Kecamatan, beberapa di antaranya sudah memiliki cukup komputer/laptop dan printer. Beberapa di antaranya lagi masih menggunakan komputer secara bergantian dengan pegawai lain sehingga waktu penyelesaian pekerjaan berkurang. Jaringan internet di wilayah Kecamatan Kejaksan terkadang juga menjadi kendala. Aplikasi SIMDA BMD sebagai pelaporan aset tetap terkadang sulit diakses di waktu kerja sehingga menghambat waktu penyelesaian pekerjaan.

Prioritas terakhir pada kendala adalah kurangnya dukungan seluruh karyawan SKPD/Unit Kerja. Ketidakpedulian karyawan selain pengurus barang dalam pengelolaan aset tetap masih ditemui di lapangan. Mereka mengganggap bahwa pengelolaan aset tetap murni tanggung jawab pengurus barang sehingga tidak ikut serta dalam mengamankan aset tetap yang ada di lingkungan SKPD.

\section{Tingkat Peranan Strategi Dalam Perbaikan Pengelolaan Aset Tetap di Kecamatan Kejaksan Kota Cirebon} Perbandingan antar elemen "Strategi" yang menempati prioritas pertama untuk perbaikan pengelolaan aset 
tetap yaitu pembinaan teknis pengelola aset tetap dengan nilai 0,222. Prioritas strategi kedua adalah pembinaan dan pengendalian dari atasan langsung dengan nilai 0,218. Prioritas ketiga adalah penerapan reward dan punishment dengan nilai 0,201. Prioritas keempat adalah sosialiasi pengelolaan aset secara berkala dengan nilai 0,148. Prioritas kelima adalah peningkatan sarana prasarana pengelola aset tetap dengan nilai 0,142 . Prioritas terakhir adalah pembuatan kebijakan mengenai pengelolaan aset tetap terbaru dengan nilai 0,069 .

Responden menilai bahwa strategi yang perlu dijadikan prioritas utama adalah pembinaan teknis pengelola aset tetap. Pendidikan dan pelatihan mengenai pengelolaan aset tetap yang pernah diberikan sebelumnya kepada pengurus barang sekota Cirebon bersifat teoritis dan terkadang sulit dipahami oleh pengurus barang SKPD sehingga tidak dapat diterapkan pada pengelolaan aset seharihari. Oleh karena itu responden berpendapat bahwa pembinaan yang bersifat teknis lebih diperlukan oleh pengurus barang karena lebih dapat diterapkan pada pengelolaan aset tetap sehari-hari.

Strategi yang dipilih untuk dijadikan prioritas kedua yaitu pembinaan dan pengendalian dari atasan langsung. Atasan langsung pengurus barang berperan dalam pengendalian pengelolaan aset tetap. Oleh karena itu atasan langsung wajib membina dan mengendalikan pengurus barang agar dapat melakukan tugasnya sesuai dengan tugas pokok dan fungsinya.

Strategi ketiga yang dipilih oleh responden adalah penerapan reward dan punishment. Baik dan tidaknya pengelolaan aset tetap kurang diberikan penghargaan dan hukuman dari pimpinan sehingga pengurus barang sebagai pemeran langsung tidak terlalu serius dalam melakukan pekerjaannya,

Strategi keempat yang dipilih responden adalah sosialiasi pengelolaan aset secara berkala. Sosialisasi pengelolaan aset secara berkala ini dilakukan kepada seluruh karyawan SKPD agar ikut membantu mengelola aset tetap di antaranya adalah mengamankan aset tetap yang menjadi tanggung jawabnya baik yang digunakan untuk mobilitas maupun yang ada di runagannya.

Strategi prioritas kelima adalah peningkatan sarana prasarana pengelola aset tetap. Sarana prasarana walau merupakan pendukung tetap harus ada untuk menunjang pekerjaan pengelola aset tetap.

Strategi terakhir yang dipilih oleh responden adalah pembuatan kebijakan mengenai pengelolaan aset tetap terbaru. Responden menganggap bahwa strategi ini tidak terlalu mempengaruhi perbaikan pengelolaan aset tetap.

\section{SIMPULAN}

Berdasarkan hasil analisis yang dilakukan pada penelitian ini, dapat disimpulkan bahwa strategi yang harus dilaksanakan terkait dengan perbaikan pengelolaan aset tetap di Kecamatan Kejaksan Kota Cirebon yaitu (1) pembinaan teknis pengelola aset tetap (2) pembinaan dan pengendalian dari atasan langsung (3) penerapan reward dan punishment (4) sosialisasi pengelolaan aset secara berkala (5) peningkatan sarana prasarana pengelola aset tetap dan (6) pembuatan kebijakan mengenai pengelolaan aset tetap terbaru.

\section{DAFTAR PUSTAKA}

[BPK RI] Badan Pemeriksa Keuangan Republik Indonesia. 2011-2016. Laporan Hasil Audit BPK atas Laporan Keuangan Pemerintah Kota Cirebon Tahun 2010, 2011, 2012, 2013, 2014, dan 2015. Bandung (ID): BPK.

Kementerian Dalam Negeri. 2016. Peraturan Menteri Dalam Negeri Nomor 19 Tahun 2016 tentang Pedoman Pengelolaan Barang Milik Daerah. Jakarta (ID): Kemendagri

Lu, Yaotai. 2011. Public Asset Management: Empirical Evidence from 
the State Governments in the United

State. Disertasi. Florida: Florida

Atlantic

University.

Rizqi LN, Domai T, Wachid A. 2013.

Penatausahaan Asset Pemerintah

Daerah Melalui Sistem Informasi

Manajemen Barang Daerah (Simbada)

Di Kabupaten Malang (Studi Pada

Bidang Asset Dinas Pendapatan

Pengelolaan Keuangan dan Asset

Kabupaten Malang). Jurnal

Administrasi Publik (JAP); Vol.1; No.1.

Malang (ID): Universitas Brawijaya.

Saaty TL. 1993. Pengambilan Keputusan

Bagi Para Pemimpin Proses hirarki

Analitik untuk Pengambilan Keputusan

dalam Situasi yang Kompleks.

Jakarta(ID): Penerbit PPM.

Saren CM, Morasa J, Wokas HN. 2016.

Evaluasi Pengelolaan Barang Milik

Daerah Pada BPK-BMD Kabupaten

Minahasa Utara. Jurnal EMBA; Vol.4;

No.4; Hal.952-963; ISSN 2303-1774.

Manado (ID): Universitas Sam

Ratulangi.

Wonggow A, Ilat V, Affandi D. 2014. Kajian Mengenai Pengelolaan Barang Milik Daerah Di Pemerintah Kota Manado Menurut Permendagri No. 17 Tahun 2007. Jurnal EMBA; Vol.2; No.1; Hal.582-593; ISSN 2303-1174. Manado (ID): Universitas Sam Ratulangi. 